DOI: https://doi.org/10.32839/2304-5809/2020-78.1-21

UDC 811.111'42

Pradivlianna Liudmyla

Vinnytsia Mykhailo Kotsiubynskyi State Pedagogical University

\title{
PARADOXES OF THE SURREALIST POETRY: LINGUISTIC APPROACH
}

Summary. The paper focuses on the problems of surrealism as a specific type of artistic thinking and takes a linguistic approach to the study of surrealist poetry. The research deals with the specifics of the poetic language of the movement which is regarded as a manifestation of "surrealist mind" and discusses peculiarities of the paradoxical images on the material of British surrealist poetry. Most of the British surrealists followed French principles of writing poems without any control exercised by reason which is regarded as the only way to evoke true images of the unconscious. A close study of the techniques used by the authors shows their attempt to create "convulsive" surrealist beauty in similes, metaphors and through the arbitrary combinations of words.

Keywords: unconscious, surrealist image, British surrealism, D. Gascoyne, H.S. Davies, Dylan Thomas.

Прадівлянна Л.М.

Вінницький державний педагогічний університет імені Михайла Коцюбинського

\section{ПАРАДОКСИ СЮРРЕАЛІСТИЧНОЇ ПОЕЗІЇ: ЛІНГВІСТИЧНИЙ ПІДХІД}

\begin{abstract}
Анотація. У статті висвітлюються проблеми сюрреалізму як специфічного типу художнього мислення та застосовуеться лінгвістичний підхід до вивчення сюрреалістичних образів. Узагальнено погляди французьких сюрреалістів на роль мистецтва та завдання, які авангардисти початку ХХ століття перед собою ставили, визначено причини парадоксальності руху. Зазначено, що ідеї Зигмунда Фрейда та його відкриття в психоаналізі підживлювали віру поетів в сили несвідомого і збуджували їхній інтерес до ірраціональних станів і мрій. Мрійливі мотиви, метаморфози людей, предметів та природних стихій, які здаються реальними та містичними водночас, створюють сюрреальність та відзначають цей міжвоенний авангардний рух. Головним критерієм поезії сюрреалізму став специфічний сюрреалістичний образ, який розуміється як складне явище з ознаками франтастичного, спонтанного, алогічного. Об'єктом та предметом дослідження стала образна система поетичних доробок британських поетів-сюрреалістів Девіда Гаскойна, Хью Сайкс Девіса та Ділана Томаса. Відзначено, що британський сюрреалізм мав менш революційний характер і обмежувався здебільшого кількома групами в Лондоні та Бірмінгемі. Більшість британських поетів дотримувалися принципів написання віршів, розроблених французькими сюрреалістами. За вченням лідера групи, Андре Бретона, «судомна» краса, до якої прагне сюрреалізм, з'являеться як сюрреалістична «іскра», коли поети зближують максимально віддалені або довільні реалії у просторі вірша, поєднують суперечливі реалії з несумісними значеннями. Тому характерними ознаками сюрреалістичного образу стали відмова від внутрішніх зв'язків слів, пошук нових значень, техніка семантичного контрасту. Це призводить до особливого збільшення використання метафрор, порівнянь. У статті виділено рівні сюрреалістичного неузгодження лексики в образах, розглянуто метафоричні та синестезійні аналогії у словосполученнях та на рівні фраз, які в цілому створюють ефект сюрреальності та отримання доступу до несвідомого.
\end{abstract}

Ключові слова: несвідоме, сюрреалістичний образ, британський сюрреалізм, Д. Гаскойн, Х.С. Девіс, Ділан Томас.

Droblem statement. The approaching anniversary of Surrealism in 2024 , one of the most influential avant-garde literary and artistic school in the culture of the twentieth century, inspires scholars of different scientific fields to reevaluate the movement and its far-reaching impacts. Surrealism has its point of departure in an assumption that man is in crisis and that "he is losing by slow degrees all reason for living" [4, p. 4]. Having established itself in numerous publications as experimental poetry, "research into human conditions" [8, p. 49], surrealism became an "attempt at a method for accessing the true nature of human perception" [Ibid.], being more concerned, as it seems, not with the aesthetic problems of art and poetry, but rather with psychological and political issues.

In Michael Benedikt's words, "surrealism's uniqueness can be traced to a paradox" [3, p. ix]. To liberate the human mind and ensure man's happiness by seeking harmony between his inner world and hard facts of life, they proposed to revise such antinomies as "life and death, the real and the imagined, past and future" [4, p. 123]. They attempted to reduce these "artificial oppositions" [3, p. xii] and resolve them "into a kind of absolute reality, a surreality" [4, p. 14]. Ideas of Sigmund Freud and his discoveries in psychoanalysis fueled their belief in the greater powers of the unconscious and excited interest in irrational states and dreams. The resulting, surrealist, image became the touchstone of surrealist poetry.

Recent research and publications. According to scholars, the unconscious has the structure of the language. In Emil Benveniste's words, the language of the unconscious has the roots in the deepest structures of the psyche and "some forms of poetry come close to dreams, discover a similar way of structuring, and introduce into the usual forms of language that disconnection from the meaning that characterizes our actions in a dream" [1, p. 123]. The scientist was convinced that surrealist poetry could give the answers to many of Sigmund Freud's questions regarding the linguistic constituent of the irrational activities of the mind.

In our research, we focus on the linguistic nature of surrealist poetry. Of greatest importance here are the discussions of surrealist poetics by J. Matthews, W. Bohn, M.A. Caws, G. Mead, A. Balaki- 
an, P. Bouissac, P. Stockwell. The basic element of our research is a surrealist image, which has been an object of quite a number of studies that demonstrate different approaches to this phenomenon.

Thus, Shelley Quinn appeals to the discoveries in the fields of neurology, psychology and psycholinguistics to suggest that surrealist poetry appeared as the result of suppression of analytical 'verbal' left hemisphere's activity and enhancement of a more creative 'visual' right one [6]. A linguistic and cognitive linguistics approach, supplemented by lingvo-stylistics and lingvo-poetics, is observed in the works of G.D. Martin, E.L. Spasskaya, P. Stockwell, J.H. Matthews and others.

This paper aims at contributing to the further study of the surrealist image and its language through observations over the poetic techniques used to develop the ideas of the unconscious. As a manifestation of a certain type of artistic thinking (in J.H. Matthews's words, "Surrealist Mind") surrealists' ideas got revealed in a specific poetic language. The study of markers of the unconscious which find their way through the language to the poem might, in the long run, give us some answers as to how unconscious expresses itself.

Presentation of the main material. Research done so far shows the surrealist tendency to a higher degree of dissonance, to increased liberation of the language from the established norms, a move away from normative perception (left hemisphere images) towards more abstract verbalization of thoughts, dream imagery, and a greater visuality of the 'right hemisphere dominant' automatic and homospatial writing. In their experimentation with this method, through the destruction of the old bonds between a word and a thought, the surrealists developed "the new system of linguistic relations, built on the basis of the spirit" [2, p. 727] and revolutionized the poetic language, bringing forth new discoveries in the poetic form.

Surrealist image is a complex phenomenon with weird, fantastic, dream-like qualities, expressed in imagistic language, freed from a narrative context. In an attempt to free the words, surrealists let loose "the hordes of words <...> as though opening a Pandora's box" [4, p. 152]. A word doesn't serve to express a thought anymore, "a word as such becomes a self-sufficient unity worthy of itself» [2, p. 87]. As Andre Breton famously asserted: "The language has been given to man so that he may make Surrealist use of it" [4, p. 32]. Whether it is only the French language that has the potential for surrealist expression and creating surreality - is still the question for discussion.

As the material for this paper, we use the poetic texts of the British surrealists. Critics state that British surrealism was less revolutionary in character and limited mostly to a few groups in London and Birmingham, which is explained by the fact that English literature "had long embodied an irrational element $<\ldots>$ in a manner so little concealed that this particular revolution no longer seemed particularly exciting" [7, p. 256]. Yet its output was vibrant and had a deep impact on British culture.

Most of the British surrealists, David Gascoyne, Hugh Sykes Davies, even Dylan Thomas who was never formally affiliated with the movement, followed French surrealist principles of writing poems without "any control exercised by reason" [4, p. 26], which is regarded as the only way to evoke true images of the unconscious. The images must combine realities as distant as possible, and it is their fusion that creates strange, 'convulsive' and marvelous beauty - the only one that the poet should deem worthy of his efforts. These paradoxical images seem absurd and contradictory but indeed appear as a result of an inquiry into the human mind by the poet who is concerned with seeking the truth. French Manifesto of Surrealism teaches: "The value of the image depends upon the beauty of the spark obtained" [4, p. 37]. We will try to classify different ways in which surrealists 'ignite sparks' in their poetry by bringing varied concepts together in a rather small poetic space, in similes, metaphors and what looks like arbitrary combinations of words.

1. Surrealist similes. These are quite rare, and the poets were not encouraged to use any kind of comparisons, for, according to the founders, "in a comparison, the spark is lacking" [4, p. 37]. Still, already in his famous first surrealist poem written in English And the Seventh Dream is the Dream of Isis Gascoyne has such lines as: a million little lamps like glowworms" and "arms are like pieces of sandpaper (Gascoyne), which, though being not particularly spectacular, give a vivid visual image in the first example and almost tactile in the second. Likewise, images from Davies's poem: the beak of a dead bird gapes like a trap and weasel's eyes like mollusks (Davies) or Thomas's: he blew like powder to the light and mother milk was stiff as sand (Thomas) make good use of comparisons to create strange and fascinating pictures.

More incomprehensible lines include: the hearts of troubadours unfold like soaked mattresses, and the wings of private airplanes look like shoeleather, and the gums of queens like the glass marbles (Gascoyne), which not so much render images, as blur different stylistic tones and create strange sensations by juxtaposing realities of varied, if not opposite, connotative potential, e.g. the poetic notion the heart of troubadours, which evokes a romantic image of medieval singers, is equated to a mundane and unpleasant soaked mattresses. In the same manner, realities with different physical characteristics are contrasted in wings of private airplanes and shoeleather, though the common seme of 'flexibility' in wings and leather unites the image and leads to the implicit comparison of an airplane with a bird.

Metaphorical similes are even rarer in such poetry and correlations between concepts are quite discernable: The mouth of time sucked, like a sponge, / The milky acid on each hinge (Thomas), <...> the night grew like a savage plant (Gascoyne). Plethora of sub-meanings in the latest example is brought to mind by enduing the night with active characteristic of growing and comparing the process with the growing of the plant described as savage - adjective, usually used to speak of an animal or force of nature which is ferocious, violent and uncontrolled.

The whole poem by Davies is built on the comparison:

It doesn't look like a finger it looks like a feather of broken glass

It doesn't look like something to eat it looks like something eaten

It doesn't look like an empty chair it looks like an old woman searching in a heap of stones... (Davies). 
We have already examined linguistic peculiarities of this poem in an earlier paper [5]. The whole poem reads like a conscious effort to explore the unconscious and create a surrealist text, based "on the belief in the superior reality of certain forms of previously neglected associations" [4, p. 26]. The realities that Davies blurs together belong to different semantic fields, grammatical categories, he mixes different syntactic constructions and uses even different graphic forms.

2. Surrealist metaphors. This is the most important and highly praised element of the surrealist poetry. Andre Breton, the leader of the movement, describes it as "one tool, and one tool only, capable of boring deeper and deeper, <..> this marvelous instrument» [4, p. 268], efficient at creating "the convulsive beauty" of surrealist image by setting side by side realities that push the opposites to extremes. Surrealist beauty is the result of the meeting of antinomies which formerly were considered incompatible. These poetic collocations take the longest time to "translate" into practical language.

Metaphoric images of the British authors demonstrate different degrees of "surrealist spark". This depends on the level of incompatibility of terms which are contrasted. Thus, such images as explosion of geranium (Gascoyne) and long worm of my finger (Thomas) are beautiful but can easily be understood because of the common semes of color or form that unite them.

More prevalent are strange, sometimes absurd, often violent images, set in the illogical contexts: the sun <...> is a bag of nails, several men <...> unloading the sea (Gascoyne), some dead undid their bushy jaws and bags of blood let out their flies (Thomas). They render surrealist atmosphere and convey multiplicity of moods and shades of tone.

Quite common are personifications: the stars, assuming shape drew in his eyes the straws of sleep (Thomas), brainless wind, arms of the night, the light awaken the endless desert, desert engrossed in its tropical slumber (Gascoyne) and sinestesia: the fading cries of the light (Gascoyne) - a complex synesthetic metaphor that combines the components of visual and sound perceptions and makes the image more capacious and, at the same time, more puzzling; A flock of banners <...> fly away like birds towards the sound of roasting meat (Gascoyne). Paradoxically, but despite the auditory and gustatory analogy, the visual images of banners, birds and meat remain dominant.
More complex, syncretic tropes, seem less automatic and more deliberate. Thus, Gascoyne's poetic image of the ocean in oceans enclasped by the arms of the night is composed of a metaphor (enclasped by the night) and metonymy (enclasped by the arms). Though extremely condensed and beautiful, it rather speaks of the conscious than unconscious mind of the poet. At the same time, they may be the proof to the words of critic C.H. Sisson who stated that Gascoyne's "own work was as surrealistic as the English language allowed" [7, p, 256].

3. Arbitrary word-combinations. They are the hardest for understanding as they are build up on sudden shifts in the sematic fields of the juxtaposed elements. They might reflect the poet's irrational unconscious mind of dreams and certainly create the necessary 'spark'. Many images seem to be arbitrary to the highest degree: that globe itself of hair and bone / That, sewn to me by nerve and brain (Thomas), the letters of the rook language are laced on the sodden leaves (Davies). They often appear in a context which 'unrolls' like a dream where odd and disconnected images follow one another: encourage the waistlines of women to expand / and the eyes of men to enlarge like pocket-cameras (Gascoyne).

The surrealist technique of semantic contrast is created by the juxtaposition of nouns and adjectives or verbs and adverbs. In these simple syntactic constructions, the poets put together lexemes of concrete and abstract semantics: crumbs of despair (Gascoyne), animate and inanimate phenomena: a still-born song (Davies), words of different perceptive semantics: night's snarl (Davies), anthropomorphic images: hysterical rain (Gascoyne).

Conclusion. Dreamlike motives, metamorphosis of humans, objects and natural elements, which seem real and mysterious at the same time, create surreality, marvelous and bewildering, and mark this inter-war avant-garde movement. Surrealist 'spark' appears when the poets use the technique of semantic contrast in syntactically simple or complex phrases and juxtapose realities with incompatible meanings. This leads to a particular increase in the use of metaphors, metaphoric similes and synesthesia. It is still hard to say whether British surrealist poets produced poetry completely freed up of conscious rational elements. Some semantic anomalies rather seem not that arbitrary as the surrealist founders demanded. But this may be an object for further study.

\section{References:}

1. Benvenist Je. (1974). Zametki o roli jazyka v uchenii Frejda [Notes on the role of the language in the teaching of Freud]. Obshhaja lingvistika [General linguistics]. Moskva: Progress.

2. Semiotika i Avangard: Antologija (2006). [Semiotics and avant-garde: anthology] ed. Ju.S. Stepanov. Moskva: Kultura.

3. Benedikt Michael (1974). The poetry of surrealism: an anthology. Boston: Little, Brown and Company.

4. Breton Andre (1969). Manifestoes of surrealism. University of Michigan Press.

5. Pradivlianna Liudmyla (2019). Surreal World of Hugh Sykes Davies: Lexical and Phonosemantic Study. Naukovij visnik Hersons'kogo derzhavnogo universitetu. Serija: Lingvistika [Scientific Bulletin of Kherson State University. Series: Linguistics], no 36, pp. 90-94.

6. Quinn S. (1985). Surrealist imagery and the right brain. Edmonton: Alberta.

7. Sisson C.H. (1971). English poetry, 1900-1950: an assessment. London: Hart-Davis.

8. Stockwell P. (2012). The surrealist experiments with language. The Routledge Companion to Experimental Literature Routledge / Ed. J. Bray. London, New York: Routledge, pp. 48-61.

\section{List of illustration materials:}

1. Gascoyne David. Poems. Available at: https://www.poemhunter.com/poem/and-the-seventh-dream-is-the-dreamof-isis/ (accessed 05 February 2020). 
2. Davies Hugh Sykes. Poetry. Available at: https://allpoetry.com/Hugh-Sykes-Davies (accessed 05 February 2020).

3. Thomas Dylan. Available at: https://www.internal.org/Dylan_Thomas (accessed 05 February 2020).

\section{Список літератури:}

1. Бенвенист Э. Заметки о роли языка в учении Фрейда. Общая лингвистика. Москва, 1974. С. $115-126$.

2. Семиотика и Авангард: Антология / ред. Ю.С. Степанов. Москва, 2006. 1166 с.

3. Benedikt Michael. The poetry of surrealism: an anthology. Boston, 1974. 375 p.

4. Breton Andre. Manifestoes of surrealism. University of Michigan Press, 1969. 304 p.

5. Pradivlianna Liudmyla. Surreal World of Hugh Sykes Davies: Lexical and Phonosemantic Study. Hayковиŭ вісник Херсонського державного університету. Серія : Лінгвістика. 2019. № 36. С. 90-94.

6. Quinn S. Surrealist imagery and the right brain. Edmonton, Alberta, 1985. 300 p.

7. Sisson C.H. English poetry, 1900-1950: an assessment. London, 1971. 267 p.

8. Stockwell P. The surrealist experiments with language. The Routledge Companion to Experimental Literature Routledge / Ed. J. Bray. London, New York, 2012. P. 48-61.

\section{Список джерел ілюстративного матеріалу:}

1. Gascoyne David. Poems. Available at: https://www.poemhunter.com/poem/and-the-seventh-dream-is-the-dreamof-isis/ (accessed 05 February 2020).

2. Davies Hugh Sykes. Poetry. Available at: https://allpoetry.com/Hugh-Sykes-Davies (accessed 05 February 2020).

3. Thomas Dylan. Available at: https://www.internal.org/Dylan_Thomas (accessed 05 February 2020). 